\title{
Transatlantica
}

Revue d'études américaines. American Studies Journal

Line Breaks in America: the Odds and Ends of Poetry

\section{Cara L. Lewis, Dynamic Form: How Intermediality Made Modernism}

\section{Yasna Bozhkova}

\section{OpenEdition}

1 Journals

\section{Electronic version}

URL: https://journals.openedition.org/transatlantica/16624

DOI: $10.4000 /$ transatlantica. 16624

ISSN: 1765-2766

\section{Publisher}

Association française d'Etudes Américaines (AFEA)

\section{Electronic reference}

Yasna Bozhkova, "Cara L. Lewis, Dynamic Form: How Intermediality Made Modernism", Transatlantica [Online], 1 | 2021, Online since 01 June 2021, connection on 01 February 2023. URL: http:// journals.openedition.org/transatlantica/16624 ; DOI: https://doi.org/10.4000/transatlantica.16624

This text was automatically generated on 1 February 2023.

\section{(c) (i) (9)}

Creative Commons - Attribution-NonCommercial-NoDerivatives 4.0 International - CC BY-NC-ND 4.0 https://creativecommons.org/licenses/by-nc-nd/4.0/ 


\title{
Cara L. Lewis, Dynamic Form: How Intermediality Made Modernism
}

\author{
Yasna Bozhkova
}

\section{REFERENCES}

Cara L. Lewis, Dynamic Form: How Intermediality Made Modernism, Ithaca, NY: Cornell University Press, 2020, Kindle Edition, ISBN 978-1501749179, 16,88€

1 Cara Lewis' book Dynamic Form: How Intermediality Made Modernism is among the most illuminating and thought-provoking recent publications exploring the intermedial experimentation that shaped literary modernism. While the idea of modernist intermediality is itself not new, and other studies have focused on the vibrant modernist interarts exchange, Lewis's book is particularly innovative and far-reaching in its understanding of intermedial form as something more dynamic and protean, often informing the work indirectly.

2 The book opens with a discussion of Virginia Woolf's 1925 essay "Pictures," which pinpoints some of the ambivalent aspects of the modernist intermedial exchange between writing and painting: while on the one hand, Woolf suggests that reading modernist works would give a reader a fairly good understanding of the works of Matisse, Cézanne, Derain, and Picasso, on the other hand she argues that it is "extremely difficult to put one's finger on the precise spot where paint makes itself felt" (Woolf 173) in modernist writing. In turn, Lewis argues that it is in the fascination with form itself that one may feel the key influence of the visual arts on modernist literature. Not limiting itself to specific examples of biographical involvement with the visual arts or of ekphrasis, the book explores how arts like painting, sculpture, film and photography often "excite" modernist literature, serving as a model for dynamic paradigms in their structure. Taking as case studies a diverse array of modernist writers who all had far-reaching connections to the visual arts-Henry James, Virginia Woolf, Mina Loy, Evelyn Waugh, and Gertrude Stein-, Lewis shows how "Modernist 
intermediality extends beyond biography and beyond ekphrasis, and visual and plastic media can make themselves felt without reference to preexisting, definable artworks." Lewis thus offers a subtle and highly perceptive understanding of how "nonliterary media can make themselves felt in the work of modernist writers."

The book challenges strict formalist assessments of modernist form which still remain influential in spite of the later critical turn away from the idea of modernism as formalism. It also demonstrates the utility of a new formalist approach, and particularly the idea of "reading for form," to discuss the intermedial dimensions of modernism. It shows that a formalist approach is not incompatible with a historicist one, allowing to combine an analysis of a work's aesthetic consideration with more historical, political, and social dimensions.

Quoting Caroline Levine's influential study Forms: Whole, Rhythm, Hierarchy, Network which calls "for expanding our usual definition of form in literary studies to include patterns of sociopolitical experience" (35) in order to dissolve "the traditionally troubling gap between the form of the literary text and its content and context," Lewis also stresses, after Levine, that the term form itself may take "conflicting, sometimes even paradoxical meanings" (Levine 2). Rethinking form not as something rigid and static but as something mobile, dynamic and often unpredictable, the book reconsiders key modernist paradigms such as Joseph Frank's "spatial form," as well as the idea of pure form and what she calls "the danger of formlessness," providing a more nuanced and enriched understanding of what constitutes intermedial modernist form. Lewis challenges Frank's seminal notion of "spatial form" precisely because it conceives of form as something static, motionless and atemporal; instead, she offers a more dynamic understanding of form, particularly in the book's first two chapters, focusing respectively on the works of Henry James and Virginia Woolf.

5 The opening chapter, titled "Plastic Form: Henry James's Sculptural Aesthetics and Reading in the Round" focuses on the idea of a "sculptural aesthetics" in James's early modernist novel The Golden Bowl (1904). Lewis shows that the artwork that provides the novel's title is part of a series of other objects-such as statues and pagodas-that are not only central to the novel's plot, but may also be interpreted meta-textually, inviting the reader to "read in the round," i.e. suggesting a mode of perception of James's dense, opaque and difficult writing which is inspired by a viewer's contemplation of a sculptural object. Lewis argues that in this novel James sought to create a reading temporality thoroughly inspired by contemplating a sculpture, making the reader incessantly return to and revisit various elements of the story's plot and style. Reading in the round, Lewis argues, transforms the novel into "a dynamic form to be processed over time, revisited, and reviewed." She thus shows that rather than a static, spatial form as Frank defined it, James creates a form marked by endless shifts in perspective and point of view, making both the characters and the reader circle around sculptural objects to fully understand the meaning of the narrative.

Lewis' groundbreaking idea of a spatial form that is not static and self-contained but dynamic and predicated on the reader's shifting perception is further deployed in Chapter 2, "Mortal Form: Still Life and Virginia Woolf's Other Elegiac Shapes," which provides an original reading of Virginia Woolf's To the Lighthouse (1927). While most intermedial readings of the novel center on Lily Briscoe's painting as a central metatextual metaphor structuring the novel's preoccupation with time, art, and memory, Lewis focuses instead on the role of the still-life composition created by a dish of fruit 
and a seashell on the Ramsays' table, which, she argues, functions as a vanitas motif foreshadowing the death of Mrs. Ramsay and the loss that the novel revolves around. Lewis' insightful analysis of how this still life is ingrained in a series of memento mori motifs in the novel, transforming the novel itself into an elegiac intermedial reflection on the notion of mortal form, is particularly moving.

Chapter 3 turns to modernist poetry, focusing on the quest for abstraction and "pure form" in the work of modernist poet and artist Mina Loy. Titled "Protean Form: Erotic Abstraction and Ardent Futurity in the Poetry of Mina Loy," this chapter is also particularly stimulating in its interpretation of Loy's poetics which may be read as a critical reflection on key visual arts issues like abstraction and purity of form. Beginning with an analysis of early poems like the sequence Songs to Joannes (1915-1917) and its relation to the Futurist aesthetics, Lewis moves on to offer insightful readings of Loy's writings that were inspired by the work of avant-garde artists she frequented, such as Wyndham Lewis or Constantin Brancusi. Lewis's analysis is particularly original in its emphasis on the idea that although Loy's poetics does at times seek to create an abstract form, this abstract form is never cold, impersonal and sterile but always enmeshed in affect and sexuality, creating what she calls an "ardent futurity," a form that is markedly different from the type of abstraction favored by many male modernists. Lewis demonstrates how what she calls Loy's "erotics of formal purity" results in protean poetic forms that are "always on the verge of merging with other forms or generating new forms," being thus exemplary of her idea of dynamic form.

The final two chapters turn to what she calls "the danger of formlessness" potentially caused by the rise of newer media like film and photography. Chapter 4, "Bad Formalism: Evelyn Waugh's Film Fictions and the Work of Art in the Age of Cinemechanics" provides a reading of a variety of works by Waugh-the novels Vile Bodies (1930) and The Loved One (1948), as well as the stories "The Balance" (1926) and "Excursion in Reality" (1932)-in order to show how in these narratives there is an underlying analogy of filmic experience, which leads to a deliberate kind of formlessness. Thus, marked by a dialectic between an excessive preoccupation with form and a dissolution into chaotic formlessness, Waugh's strategic "bad formalism" is to be read, Lewis argues, as a sign of his attempt to allegorize and ironically reflect on his own status as a late modernist writer, whose writing is threatened by the rise of the cinema as a popular art form.

9 The final chapter, titled "Surface Forms: Photography and Gertrude Stein's Contact History of Modernism," focuses on Gertrude Stein's The Autobiography of Alice B. Toklas (1933). Examining Stein's use of photography, both as actual illustrations and as photographic metaphors, she shows how Stein uses an aspect rarely associated with the idea of form-surface-in order to secure her place in the history of modernism, amongst famous writers and artists. Lewis suggests that the surface form of the photograph reflects the novel's deliberate and experimental superficiality, and is integrated in Stein's attempt to document the modernist movement as a network, which constitutes another kind of dynamic form.

Lewis' highly perceptive and far-reaching study will be of use not only to scholars working specifically on the authors she discusses, but to anyone interested in the intersections between literature and the arts in the modernist period. She persuasively shows how different kinds of modernist literary works are thoroughly shaped by an attention to another art. While indeed the scope of the book is more than satisfactory, 
one may wonder why Lewis chose to focus on those authors in particular. While some, like Woolf, Loy and Stein, had ample biographical connections with artists and interest in the visual arts, Waugh himself is not so obviously connected to a modernist aesthetic in the first place, so one may wonder why Lewis chose to discuss his work in particular. While the idea of a protean, dynamic form is carried out quite convincingly in the first three chapters, the last two seem to stray in a different direction-with the ideas of formlessness and surface less obviously connected to the book's main thesis of a protean dynamism. One of the aspects that particularly invite further debate would be the notion of "formlessness," as well as the opposition that she makes between "too much" and "too little form," since it is not entirely clear what constitutes "the aesthetics of bad formalism." One may also regret that of the book's five chapters only one focuses on poetry, neglecting in particular the important confluence of the experimental modernist poetics with the nascent language of film, and especially the experimental technique of filmic montage, which has been documented in key studies such as Susan McCabe's Cinematic Modernism: Modernist Poetry and Film. After the brilliant chapter on Loy's protean visual poetics, it would have been interesting to pursue further the idea of dynamic form in relation to film in the work of some other modernist poets.

\section{BIBLIOGRAPHY}

FRANK, Joseph. The Idea of Spatial Form. New Brunswick, NJ: Rutgers University Press, 1991.

LEVINE, Caroline Levine. Forms: Whole, Rhythm, Hierarchy, Network. Princeton, NJ: Princeton University Press, 2015.

MCCABE, Susan. Cinematic Modernism: Modernist Poetry and Film. Cambridge: Cambridge University Press, 2005.

WOOLF, Virginia. "Pictures." The Moment and Other Essays. New York: Harcourt, 1974, p. 173-178.

\section{AUTHORS}

\section{YASNA BOZHKOVA}

Université Sorbonne Nouvelle 